\begin{tabular}{|c|c|c|} 
Available online at: http://ejournal-balitbang.kkp.go.id/index.php/ifrj \\
e-mail:ifrj.puslitbangkan@ @mail.com \\
INDONESIANFISHERIESRESEARCHJOURNAL \\
Volume 23 Nomor 1 June 2017 \\
p-ISSN: 0853-8980 \\
e-ISSN: 2502-6569
\end{tabular}

\title{
COMPARISON OF INDONESIAN TUNA LONGLINE FISHING PERFORMANCE WITHIN AND OUTSIDE INDONESIA EXCLUSIVE ECONOMIC ZONE (EEZ)
}

\author{
Bram Setyadji¹ and Irwan Jatmiko ${ }^{1}$ \\ ${ }^{1}$ Research Institute for Tuna Fisheries, Mertasari Road, No. 140 Br. Suwung Kangin, Desa Sidakarya, Denpasar Selatan, \\ Denpasar-Bali, Indonesia 80224 \\ Received; August 08-2016 Received in revised from December 16-2016; Accepted December 23-2016
}

\begin{abstract}
Indonesian tuna longline fleets have been fishing in the Exclusive Economic Zone (EEZ) and high seas of the Indian Ocean for quite some time. However, effort has never been made to separate catch from the EEZ and the high seas as it important for fisheries management. A total of 2,430 set-by-set longline fishing data had been collected by scientific observers based in the Research Institute of Tuna Fishery in Bali since August 2005 to December 2014 on which present analysis was made. The research aims to compare between trend of tuna catch of the EEZ and of the high seas of Indian Ocean. The results show that the mean hook rate of both catches of big eye tuna (BET) and southern Bluefin tuna (SBT) caught in the high seas was significantly higher than that the EEZ (two sample t-test, $p<0.05$ ), while for yellow fin tuna (YFT) it was in the opposite direction (two sample t-test, $p<0.05$ ). As for albacore (ALB), the mean hook rate value was statistically similar in both fishing grounds (two sample t-test, $p>0.05$ ).
\end{abstract}

\section{Keywords: Tuna; Iongline; Exclusive Economic Zones; hook rate}

\section{INTRODUCTION}

Indonesian EEZ extends 2.7 million $\mathrm{km}^{2}$, almost a half of the entire Indonesian marine waters of $5.8 \mathrm{~km}^{2}$. In terms of size, the Indonesian EEZ ranks number $4^{\text {th }}$ after Australia, France OT and India. In the context of fisheries management, Indonesian waters is divided into eleven Fisheries Management Areas (FMA), three of them (FMA 571, 572 and 573) are located within the IOTC area of competence (Irianto et al., 2016). In the past years (2008-2014) tuna catch of Indonesia considered high and representing over one fifth of the total catches of IOTC member countries. The national catch of four main tuna species in 2015 was estimated 135,799 tons which composed of yellowfin tuna $(35,060 \mathrm{t})$, bigeye tuna $(22,433 \mathrm{t})$, skipjack tuna $(70,206 \mathrm{t})$ and albacore (8,080 t) (Irianto et al., 2016).

Some papers describied historical catch and catch per unit of fishing effort trends of Indonesian tuna longline fishery, among others is Marcille et al. (1984), who analyzed catch data of P.T. Perikanan Samodra Besar collected in the years 1973-1981. Gafa et al. (2000), Eddrisea et al. (2008) and Sadiyah et al. (2011b) had extended the analysis of the catch data from the same company for the years 1978-1995. Furthermore, on the basis of analysis of scientific observer data of 2005-2007, Sadiyah et al. (2011a) recommended the need for hook rate standardization owing to the varied size of fishing vessel used. Meanwhile no attempt has been made to separate catch on the basis of two big fishing zones, namely the EEZ and the high seas. This paper presents catch analysis addressing the catch of the two fishing zones with the objective to obtain knowledge on the pattern of tuna fishing and its distribution in the Indian Ocean.

\section{MATERIALS AND METHODS}

A total of 2,430 set-by-set fishing data of tuna longline fleets based in Muara Baru (Jakarta), Palabuhanratu (West Java) and Benoa (Bali) for the period of August 2005 to December 2014 were collected by the scientific observer. (Figure 1). The dataset covers fishing date, fishing location and gear deployment, number of hooks and amount of catch in terms of number. Fishing performance as described in this paper is represented as hook rate, namely, the number of fish caught per 100 of hooks. As for the delineation of EEZ, it was obtained from the digitalization of map attached to the Ministerial Regulation No. 18/PERMEN-KP/2014. In the process the $1: 10 \mathrm{~m}$ physical land vectors were obtained from http://www.naturalearthdata.com as per 19 August 
2015, whereas the fishing areas recorded by the Food and Agricultural Organization (FAO) were obtained from http://www.marineregions.org/downloads.php as per 19 August 2015.

The species analyzed in this paper limited to four main large tuna species, namely yellowfin tuna,
Thunnus albacares (YFT), bigeye tuna, T. obesus (BET), albacore, T. alalunga (ALB) and southern bluefin tuna, T. maccoyii (SBT). The QGIS 2.10.1Pisa was used for any spatial data analysis while for statistical analysis we used $\mathrm{R}$ version 3.2.1 ( $\mathrm{R}$ Core Team, 2016).

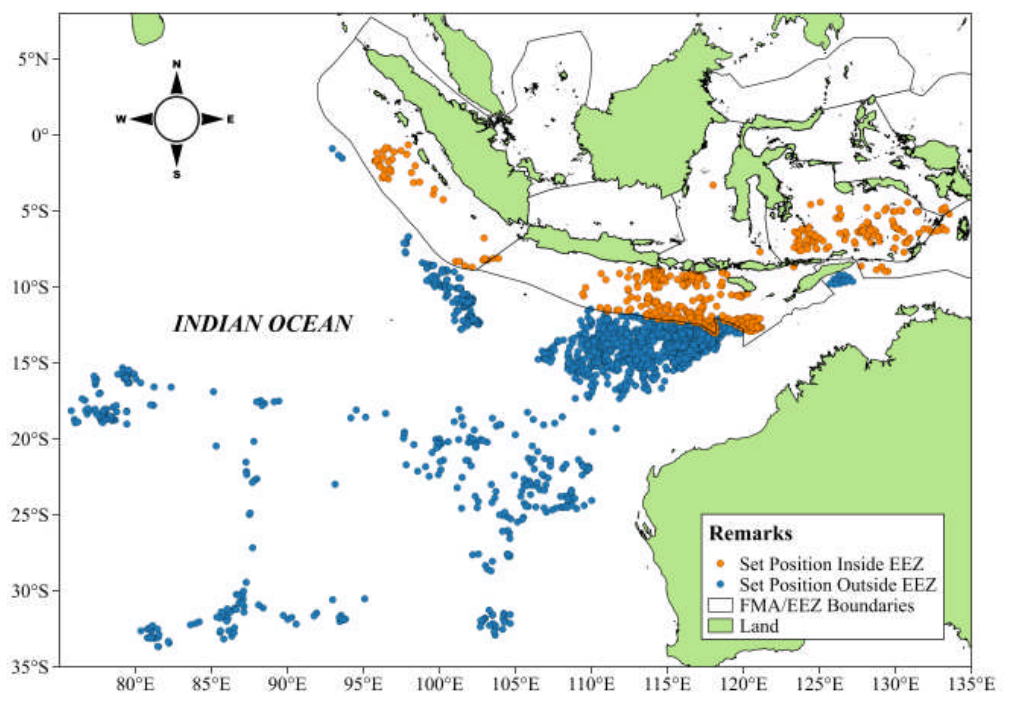

Figure 1. Geographic location of Indonesian tuna longline fishing 2005-2014 within and outside the Indonesian EEZ.

About 558 set data of positions were intersected within the EEZ, while the rest (1,867 set positions) were registered outside the EEZ. QGIS used to plot, the hook rate per set was plotted and then converted into ESRI shape file (.shp). The hook rate shape file was marked and distinguished by area (in/out EEZ) using Spatial Query plugin. After the points were selected it was then separated from the original vector layer using Clip plugin inside the Geoprocessing tools. The clipped vector layer then spatially joined. The new joint attributes layer was then extracted as Excel file.

The mean hook rates were calculated based on the desired area (in/out EEZ). In order to investigate any significance of fishing performance (mean hook rate) between inside and outside Indonesian EEZ, the Welch two sample t-test analysis was undertaken with the hypothesis $\left(\mathrm{H}_{0}\right)=$ that there is no different of the mean hook rate of all tuna species within EEZ and outside EEZ. Before conducting t-test, Levene's test inside the $\mathrm{R}$ was conducted to assess the equality of variances for a variable calculated. Zero catch per set also considered in the analysis.

\section{RESULTS AND DISCUSSION Results}

Of total 2,430 of catch per set data available, five were omitted from analysis due to dubious geographic information. Mean catch of ALB, BET and SBT outside EEZ (4.028/set, 3.173/set, 0.144/set, respectively) was higher than that of within EEZ (2.319/set, 1.844/ set, $0.045 /$ set, respectively), on the other hand the mean catch of YFT outside EEZ (0.884/set) was lower compared to within EEZ (1.935/set). Fishing performance from Indonesian tuna longliners outside EEZ was better compared to that within EEZ, except for YFT. The percentage of zero catch per set was high (above 50\%) for ALB within EEZ, YFT outside EEZ and SBT for both areas (Table 1).

Table 1. Mean nominal catch and hook rate for tuna caught by Indonesian longliners from 2005-2014 within and outside the EEZ

\begin{tabular}{lrrrrr}
\hline & \multicolumn{2}{c}{ Within EEZ } & \multicolumn{2}{c}{ Outside EEZ } \\
\hline Species & $\begin{array}{c}\text { Mean catch } \\
\text { (no. fish/set) }\end{array}$ & $\begin{array}{c}\text { Mean hook rate } \\
\text { (no.fish/100 hooks) }\end{array}$ & $\begin{array}{c}\text { \% zero catch } \\
\text { per set }\end{array}$ & $\begin{array}{c}\text { Mean Catch } \\
\text { (no. fish/set) }\end{array}$ & $\begin{array}{c}\text { Mean hook rate } \\
\text { (no. fish/100 hooks) }\end{array}$ \\
\hline ALB & 2.319 & 0.233 & $58.06 \%$ & 4.028 & 0.271 \\
YFT & 1.935 & 0.186 & $36.74 \%$ & 0.884 & 0.070 \\
per set
\end{tabular}


Both BET and SBT caught outside the EEZ significantly have higher mean hook rate compared to that within the EEZ (two sample t-test, $\mathrm{p}<0.05$ ), while for YFT was the opposite (two

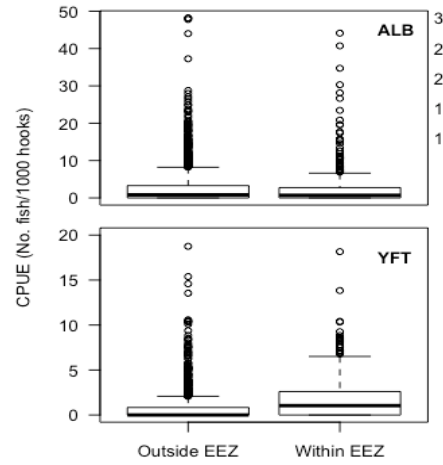

sample t-test, $\mathrm{p}<0.05)$. As for ALB, the mean hook rate value was statistically comparable in the two fishing grounds (two sample t-test, $\mathrm{p}>0.05$ ) (Figure 2, Table 2).

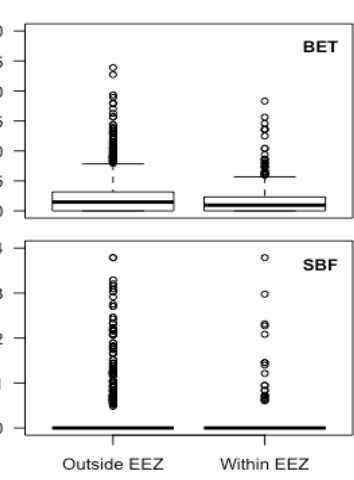

Figure 2. Boxplot diagram of mean hook rate from all tuna species caught by Indonesian tuna longliners within and outside the EEZ.

Table 2. Summary of Welch's two sample t-test table from all tuna species caught by Indonesian tuna longliners within and outside the EEZ

\begin{tabular}{|c|c|c|c|c|c|c|c|c|}
\hline \multirow[b]{2}{*}{ Species } & \multicolumn{4}{|c|}{ Meanhook rate in group } & \multirow[b]{2}{*}{ df } & \multirow[b]{2}{*}{$\mathbf{t}$} & \multirow[b]{2}{*}{$p$-value } & \multirow[b]{2}{*}{ Signif. } \\
\hline & $\begin{array}{l}\text { Within } \\
\text { EEZ }\end{array}$ & $\begin{array}{l}\text { No. } \\
\text { Set (n) }\end{array}$ & $\begin{array}{l}\text { Outside } \\
\text { EEZ }\end{array}$ & $\begin{array}{l}\text { No. } \\
\text { Set (n) }\end{array}$ & & & & \\
\hline BET & 0.166 & 558 & 0.233 & 1,867 & $1,043.80$ & -5.6675 & 1.87E-08 & $\star * *$ \\
\hline YFT & 0.185 & 558 & 0.069 & 1,867 & 603.96 & 6.4512 & $2.28 \mathrm{E}-10$ & *** \\
\hline ALB & 0.233 & 558 & 0.270 & 1,867 & $2,423.00$ & -1.5615 & 0.1185 & \\
\hline SBT & 0.003 & 558 & 0.010 & 1,867 & $1,685.40$ & -4.8989 & $1.06 \mathrm{E}-06$ & *** \\
\hline
\end{tabular}

Within the EEZ, both YFT and BET showed declining trend over the years. As for high seas fishery (outside EEZ), there was a slight increasing trend for BET but relatively stable for YFT. Mean hook rate of

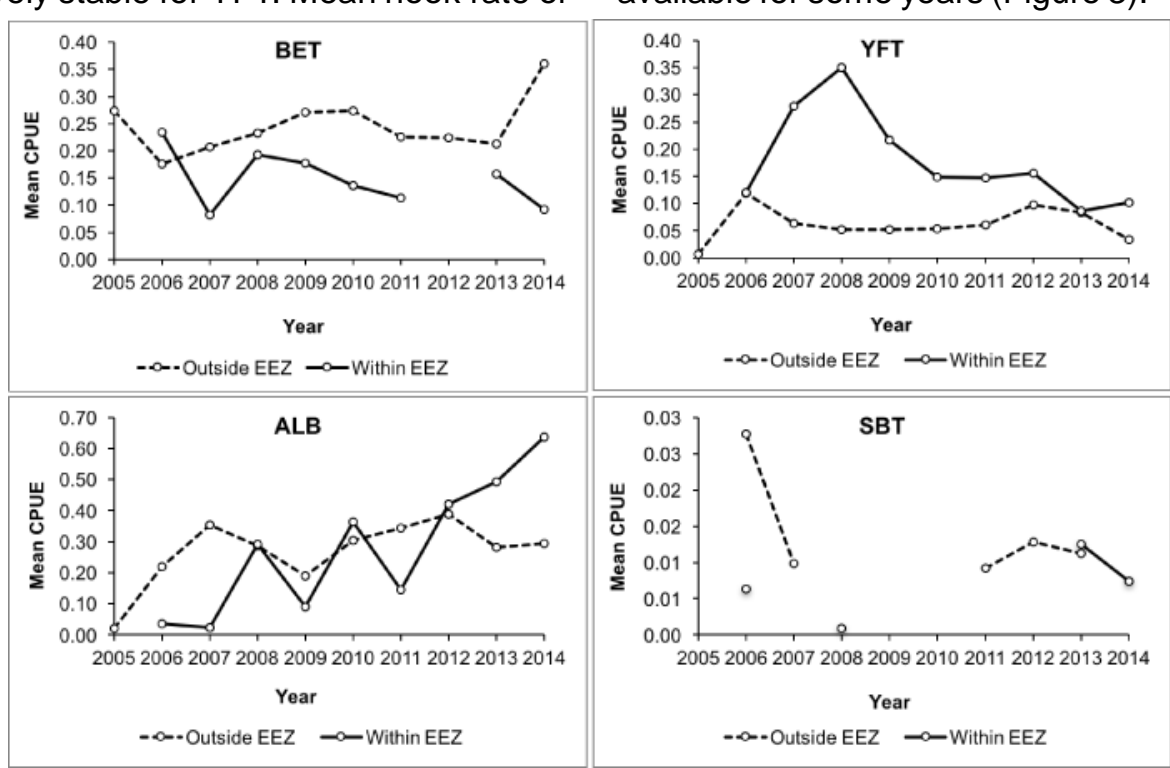

Figure 3. Comparison of annual mean hook rate (CPUE) for all tuna species caught by the Indonesian tuna longliners within and outside the EEZ.
ALB has shown promising upraise over the years both within and outside EEZ. On the other hand, no analysis was conducted for SBT as no catch data available for some years (Figure 3 ). 


\section{Discussion}

There were some difficulties in term of analyzing the fishing performance of Indonesian tuna longliners using the hook rate data. This is due to lack of publications related to the stock assessment or standardization on nominal hook rate in particular. The only work was a paper published by Sadiyah et al. (2012) concering on standardization of hook rate based on scientific observer data. The idea of separating the fishing performance based on EEZ (within/outside) was, during the period of the seventies to early nineties, the fishing ground of Indonesian tuna longliners concentrated within the EEZ (FMA 572, 573 and 714) (Sadiyah et al., 2011b). Therefore, it is assumed that with high intensity of fishing in a limited fishing ground will result in intense pressure on the fishery. The fishing pressure affected on the hook rate of YFT, since reached its peak (around 1.00) in 1982 and continued to drop in the following years to as low as 0.11 . As for another species, the mean hook rate tends to rise after 1990 (Figure 4).

The low catches within the EEZ for BET, ALB and SBT seem to have related to the use of deep longline gear configuration since 1983, which targeting BET rather than YFT (Sadiyah et al., 2011a). Most of the YFT caught when the fishermen using shallow longline configuration (between 5-7 hooks between float). This perhaps because they know that YFT preferred to spend more of the time inhabit shallower depth layer (Dagorn et al., 2006; Cayré, 1991; Bigelow et al., 1999). On the other hand, BET mostly caught during deep longline configuration (more than 14 hooks between float). This likely because, even though BET has similar vertical migration behavior as YFT, but their distinct diurnal behavior which frequently visited deeper, cooler waters during the day and shallower warmer waters during the night as recognized by the fishermen by setting the gears in the morning (Musyl et al., 2003; Evans et al., 2008).

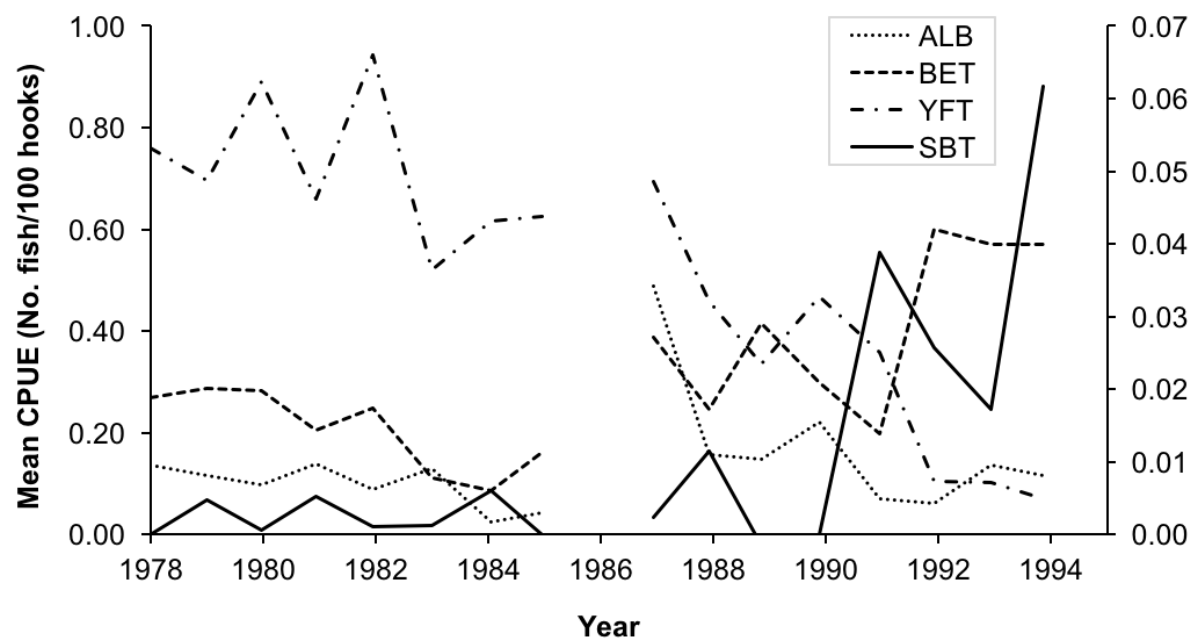

Figure 4. Time series of annual mean nominal hook rate for the four main tuna species (BET, YFT, ALB, SBT) (Graph was reproduced from Sadiyah et al., 2011).

Through the analysis, Indonesian longliners might have some options regarding their fishing strategy. If the target species is YFT, fishing within the EEZ using shallow longline configuration allegedly more favorable. Whereas if the target species is BET, it would be more beneficial when fishing outside the EEZ. ALB caught in both fishing zones (within and outside EEZ) as they inhabit in the area of $10^{\circ}-15^{\circ} \mathrm{S}$ for mature ALB and in the area of $15^{\circ}-35^{\circ} \mathrm{S}$ (Setyadji et al., 2014). In practice, however, most skippers frequently change their target species. This was facilitated by modifying a specific fishing technique, but very often also by a combination of fishing techniques. This resulted in the fluctuation of the catch rate and sometimes even low catch rate. The Japanese and the Korean fleets have higher CPUE which is probably because they set one or two species as target (bigeye tuna with swordfish or southern bluefin tuna with albacore), and using specific longline configuration while consistently fishing at their known fishing ground (Sadiyah et al., 2011b; Lee et al., 2014; Ochi et al., 2014).

The number of registered Indonesian longline vessels operated, as reported to IOTC as per 2 November 2016 in the FMAs 572, 573 were 1,311, with $79 \%$ of them $(1,022$ units were above $50 \mathrm{GT})$ (Irianto et al., 2016). The actual number may be less than 500 vessels due to the impact of the Ministry Regulation No.10/2015 regarding moratorium for exforeign fishing vessels as well as the impact of the Minister Regulation No.57/2014 on prohibition of transshipment among longline vessels within the 
Indonesian EEZ. Alternatively, choosing the target species according to fishing ground could be a good alternative to the business. YFT and ALB catch in fresh condition (less than 14 days) normally originated from vessels fishing in the EEZ, while for frozen tuna catch, such as for BET, ALB and SBT came from vessels fishing outside the EEZ with longer period of days at sea.

\section{CONCLUSION}

Result of the study indicates that the mean hook rate of $B E T$ and SBT for fishing in the EEZ was higher than that for fishing in the high seas. On the other hand, mean hook rate of YFT was higher in the EEZ than in the high seas. As for ALB, the mean hook rate shows no difference between the two fishing areas.

\section{ACKNOWLEDGEMENT}

The Authors would like to thank to all scientific observers of Research Institute for Tuna Fisheries (RITF) for their contribution in collecting data during $2005-2014$.. We also would like to extend our gratitude to various organizations, namely, the Commonwealth Scientific and Industrial Research Organization (CSIRO), the Australian Centre for International Agricultural Research (ACIAR) and the Research Center for Capture Fisheries (RCCF) for their funding support through research collaborative project FIS/2002/074: Capacity Development to Monitor, Analyze and Report on Indonesian Tuna Fisheries.

\section{REFERENCES}

Bigelow, K.A., Hampton, J. \& Miyabe, N. (1999). Effective longline effort within the yellowfin habitat and standardized CPUE. Working paper on standing committee on tuna and billfish, 16-23 June 1999, Tahiti.

Cayré, P. (1991). Behaviour of yellowfin tuna (Thunnus albacares) and skipjack tuna (Katsuwonus pelamis) around fish aggregating devices (FADs) in the Comoros Islands as determined by ultrasonic tagging. Aquat. Living Resour. 4, 1-12. DOI: http://dx.doi.org/10.1051/alr/1991000

Dagorn, L., Holland, K.N., Hallier, J.P., Taquet, M., Moreno, G., Sancho, G., Itano, D.G., Aumeeruddy, R., Girard, C., Million. \& Fonteneau, J.A. (2006). Deep diving behavior observed in yellowfin tuna (Thunnus albacares). Aquat. Living Resour. 19, 85-88. DOI: 10.1051/alr: 2006008.
Evans, K., Langley, A., Clear, N.P., Williams, P., Patterson, T., Sibert, J., Hampton, J. \& Gunn, J.S. (2008). Behaviour and habitat preferences of bigeye tuna (Thunnus obesus) and their influence on longline fishery catches in the western Coral Sea. Can. J. Fish. Aquat. Sci. 65, 2427-2443. DOI: 10.1139/F08-148.

Eddrisea, F., D. Nugroho, S. Fujiwara, K. Itoh. \& Nishida, T. (2008). Atlas of Tuna Fisheries and Resources in Indonesia (Indian Ocean) OFCF Tuna Atlas Project in the IOTC Waters: Atlas Series No.2 Indonesia.

Gafa, B. S., Bahar, I. R., Anung, A., Prisantoso, B. I., Mahiswara, Rachmat, E., Susanto, K., Uktolseja, J., Radiarta, I. N. \& Nishida, T. (2000). Analyses of the Indonesian tuna longline fisheries data in the Indian Ocean (1978-1994). Second Session of the IOTC Working Party on Tropical Tunas. Victoria, Seychelles, 23-27 September 2000. IOTC-2000- WPTT-13.

Irianto, H.E., Wudianto., Satria, F. \& Nugraha, B. (2013). Tropical tuna fisheries (in the Indian Ocean of Indonesia. Paper presented on fifteen Working Party on Tropical Tunas, Spain, 23-28 October 2013.

Irianto, H.E., Wudianto, Fahmi, Z., Setyadji, B., Satria, F., Sadiyah, L., Nugraha, B. \& Widodo, A.A. (2016). Indonesia National Report to the Scientific Committee of the Indian Ocean Tuna Commission. A paper presented at the IOTC 19th Scientific Committee in Seychelles, IOTC-2016SC19-NR10. $26 \mathrm{pp}$.

Lee, S.I., Kim, Z.G., Lee, M.K., Ku, J.E., Park, W.P. \& Lee, D.W. (2014). CPUE standardization of bigeye tuna caught by Korean tuna longline fishery in the Indian Ocean. Paper presented on Sixteenth Session of the IOTC Working Party on Tropical Tunas. Bali, Indonesia, 15-19 November 2014.IOTC-2014-WPTT16-30.10 pp.

Marcille, J., Boely, T., Unar, M., Merta, I.G.S., Sadhotomo, B. \& Uktolseja, J. C. B. (1984). Tuna Fishing in Indonesia, Paris, l'ORSTOM. Institute Francais de Recherche Scientifique Pour le Developpement en Cooperation.

Musyl, M.K., Brill, R.W., Boggs, C.H., Curran, D.S., Kazama, T.K. \& Seki, M.P. (2003). Vertical movements of bigeye tuna (Thunnus obesus) 
associated with islands, buoys, and seamounts near the main Hawaiian Islands from archival tagging data. Fish. Oceanogr. 12(3), 152-169. DOI: 10.1046/j.1365-2419.2003.00229.x.

Ochi, D., Matsumoto, T., Satoh, K. \& Okamoto, H. (2014). Japanese longline CPUE for bigeye tuna in the Indian Ocean standardized by GLM. Paper presented on Sixteenth Session of the IOTC Working Party on Tropical Tunas. Bali, Indonesia, 15-19 November 2014. IOTC-2014-WPTT16$29.28 \mathrm{pp}$.

R Core Team. (2016). R: A language and environment for statistical computing. R Foundation for Statistical Computing, Vienna, Austria. URL: https://www.R-project.org/.
Sadiyah, L., Dowling, N. \& Prisantoso, B.I. (2011a). Changes in fishing pattern from surface to deep longline fishing by the Indonesian vessels operating in the Indian Ocean. Ind.Fish.Res.J. 17 (2), 87-99.

Sadiyah, L. \& Prisantoso, B.I. (2011b). Fishing strategy of the Indonesian tuna longliners in Indian Ocean. Ind.Fish.Res.J. 17 (1), 29-35.

Sadiyah, L., Dowling, N. \& Prisantoso, B.I. (2012). Developing recommendations for undertaking CPUE standardisation using observer program data. Ind.Fish.Res.J. 18 (1), 19-33.

Setyadji, B., Nugraha, B. \& Nugroho, D. (2014). Length-weight relationship, size distribution and annual CPUE's of albacore in eastern Indian Ocean. Ind.Fish.Res.J. 20(1), 17-22. 